\title{
A STUDY ON JOB SATISFACTION OF EMPLOYEES IN TAMIL NADU WITH SPECIAL REFERENCE TO TBF, KUMBAKONAM
}

\author{
S. Ramya \\ Research Scholar,(Part time), PG and Research Department of Commerce, Government Arts \\ College (A),Affiliated to Bharathidasan University, Kumbakonam -02. \\ Dr. A. Balu \\ Ph.D., Assistant Professor and Head and Research Supervisor, PG and Research \\ Department of Commerce, Government Arts College (A), Affiliated to Bharathidasan \\ University, Kumbakonam -02.
}

\begin{abstract}
Employee is a back bone of every organization, without employee no work can be done. Employed individuals spend a majority of their adult life making a living for themselves and their families. Objectives of the study. To study the job satisfaction of employees in TBFKumbakonam and to learn the factors influencing and affecting job satisfaction of employees in TBFKumbakonam. Descriptive and Conclusive in Nature of the research design adopted in this study.primary as well as secondary data have been used in this study.Primary data collected through structured questionnaire. Important findings of the study. It was found that almost all the respondents have registered their positive opinion about the experience they obtain in their work. Only a few respondents do not have any opinion and another few expressed that their rest interval is not adequate and inadequate facilities to attend their job. Suggested in this study, Redressing grievances, then and there to keep the employee and their colleagues relationship intact and provide relaxation techniques like yoga and meditation may be arranged by the organization. Conclude this study. As employees services are considered as emerging field, the problems of the employees will definitely affect their profession and so conflicts in all the aspects should be eliminated.
\end{abstract}

Keywords: work pressure, work environment, superiors, training etc.

\section{INTRODUCTION}

Employee is a back bone of every organization, without employee no work can be done. Employed individuals spend a majority of their adult life making a living for themselves and their families. Considering on average people spend most of their working lives in a working environment, it then stands to reason that people should endeavour to be satisfied at work if humans are always in pursuit of happiness. So employee's satisfaction is very important. Employees will be more satisfied if they get what they expected, job satisfaction relates to inner feelings of workers. Job satisfaction refers to an individual's 
general feelings or preference of individual or ones attitudes towards his/her job and extent to which one is content with it. This feeling is based on an individual's perception of satisfaction and influenced by a person's ability to complete required tasks, the level of communication in an organization, and the way management treats employees. A person with a high level of job satisfaction holds positive attitudes about the job, while a person who is dissatisfied with his or her job holds negative attitudes about the job. They are in a positive mood and often able to improve in areas of brainstorming, decision making, and problem solving. To be more precise academic researchers and human resource professionals have defined varying categories of satisfaction.

\section{II.REVIEW OF LITERATURE}

"Shanmukha Rao Padala (2010)", in his research on study of employee job satisfaction on Nagarjuna fertilizers and chemicals Limited (Kakinada), has stated that work environment influence worker's expectation which result in Job satisfaction In turn organizational commitment can help workforce innovate, be proactive in work place and act upon with high morale. The study revealed that age, education, nature of job, length of service and income has negative relation with job satisfaction. Employees having active participation with trade union were found to have more job satisfaction and organizational commitment.

"Daljeet Singh Wadhwa, et al., (2011)", in their research have conducted a study on Cement factory of Chhattisgarh to know more about how job satisfaction is related to behavioural, organizational and environmental factors and observed it to be positively related. Equal and fair treatment of employees and proper supervision can enhance their level of satisfaction towards their job.

Research by "Nasrin Arshadi,(2010)", based on self-determination theory investigated relations among autonomy, support, need satisfaction, work motivation and job performance. The study was based on an industrial unit in Iran. Autonomy reflects the need to actively determine own behaviour and experience mastery at work based on selfdetermined behaviour without the influence of others. Autonomy could be of supportive in nature or controlling. Supportive autonomy promotes self-motivation, need satisfaction and relate positively to work motivation and job performance. This study helped to test the SDT model.

"Tugba Dundar, et al, (2012)", in their research tried to understand the teacher's organizational justice perceptions and job satisfaction levels at primary school in Fatih province of Istanbul. Organizational justice includes rules, process, awards and punishment. Job related dimensions used for the study were job specification and job, wage, development potentialities, working conditions, interpersonal relations, organizational environment and job satisfaction. Study results proved to have positive significant correlation between primary teachers' organizational justice perception and job satisfaction levels. The longer the years of service of the teacher in the school and the more their experience level, the better is their trust, respect and view over school management. 


\section{STATEMENT OF THE PROBLEM}

The review of literature on the job satisfaction shows that different researchers examined the concept on different dimensions like: autonomy, responsibility, variety, nature of job, communication network, democratic functioning, public and private sector, relation with controlling officers and colleagues, attitudes and morale, salary and allowances, promotion prospects, work place conditions, recognition, intrinsic and extrinsic rewards, job security, absenteeism, turnover, tardiness, job dissatisfaction, sabotage and low levels of performance in the job, child care center, interesting and challenging work, feeling of achievement etc. The earlier research shows that the factors like increased productivity, survival and effectiveness of organization, organizational success, keep the interest of the organization, absenteeism, personnel turnover, tenure.

\section{IV.OBJECTIVES OF THE STUDY:}

The following objectives have taken from this study.

1. To study the job satisfaction of employees in TBFKumbakonam.

2. To learn the factors influencing and affecting job satisfaction of employees in TBFKumbakonam.

\section{V.RESEARCH METHODOLOGY}

\begin{tabular}{|l|l|}
\hline Item & Description \\
\hline Research Design & Descriptive and Conclusive in Nature \\
\hline Type of Population & $\begin{array}{l}\text { Town Benefit fund employees employed in collection, deposit, office } \\
\text { staff employees at Kumbakonam of Tamilnadu }\end{array}$ \\
\hline Population Source List & Obtained from TBF Kumbakonam \\
\hline Sample source & Derived from the population source of selected TBF Kumbakonam \\
\hline Sampling Method & Town Benefit fund at Kumbakonam \\
\hline Sample Size & Probability method under lottory method adopted \\
\hline Sampling Plan & $\begin{array}{l}\text { Collection employees, office employees, Chit fund section all section of } \\
\text { TBF }\end{array}$ \\
\hline Sources of Data & Both Primary and Secondary Data \\
\hline $\begin{array}{l}\text { Sources of Primary } \\
\text { Data }\end{array}$ & $\begin{array}{l}\text { Obtained from the respondents of TBF through structured questionnaire } \\
\text { with interview schedule }\end{array}$ \\
\hline $\begin{array}{l}\text { Sources of Secondary } \\
\text { Data }\end{array}$ & $\begin{array}{l}\text { Gathered from the previous studies, government related gazette, census } \\
\text { and periodicals }\end{array}$ \\
\hline $\begin{array}{l}\text { Nature of } \\
\text { Questionnaire }\end{array}$ & \begin{tabular}{l} 
A structured questionnaire with suitable scaling \\
\hline Types of Questions
\end{tabular} \\
\hline
\end{tabular}




\begin{tabular}{|l|l|}
\hline Pre testing & $\begin{array}{l}\text { The questionnaire was pre tested for its validity and reliability among the } \\
\text { selected respondents, opinion leaders who are actively presenting in the } \\
\text { industry. Based on their opinion some of the modifications were drawn } \\
\text { and restructured questionnaire was used for the survey purpose }\end{array}$ \\
\hline Testing of validity & Was done to check the content, criteria validity \\
\hline Testing of Reliability & Cronbach alpha value $(0.7723$ or $77 \%)$ \\
\hline Statstical tools used & Chi-square, ANOVA and data reduction analysis \\
\hline $\begin{array}{l}\text { Other analytical tools } \\
\text { used }\end{array}$ & Percentage and Cross tables \\
\hline
\end{tabular}

The following variables have been taken for this study (objectives 1)

\begin{tabular}{|l|l|l|}
\hline Factors & & Variables \\
\hline WORK EXPERIENCE & 1 & The working hours are comfortable \\
\cline { 2 - 3 } & 2 & The work load is excessive \\
\cline { 2 - 3 } & 3 & The rest intervals are adequate \\
\cline { 2 - 3 } & 4 & Adequate facilities are provided to attend my job \\
\cline { 2 - 3 } & 5 & $\begin{array}{l}\text { The work place is free from dust, noise pollution and there } \\
\text { is proper lighting / ventilation. }\end{array}$ \\
\hline \multirow{2}{*}{$\begin{array}{l}\text { WELATIONSHIP SUPERIORS } \\
\text { RELATIONSHIP }\end{array}$} & 6 & I have got an easy approach to my boss \\
\cline { 2 - 3 } WITH COLLEAGUES & 7 & My superiors appreciate my performance \\
\cline { 2 - 3 } & 8 & My superiors respects my opinion / criticism \\
\hline
\end{tabular}

The following variables have been taken for this study (objectives 2)

\begin{tabular}{|c|c|c|}
\hline Factors & & Variables \\
\hline \multirow{5}{*}{$\begin{array}{l}\text { MOTIVATION AND } \\
\text { RECOGNITION }\end{array}$} & 1 & I find my job interest and prospective \\
\hline & 2 & I feel satisfied when my performance is recognized \\
\hline & 3 & I feel proud to work in my organization \\
\hline & 4 & $\begin{array}{l}\text { My performance is recognized by increment in my } \\
\text { salary }\end{array}$ \\
\hline & 5 & I am satisfied with the promotion policies \\
\hline \multirow[t]{2}{*}{ SALARY } & 6 & The salary is commensurate with my efforts \\
\hline & 7 & I want a change in my present pay scale. \\
\hline \multirow[t]{4}{*}{ WELFARE FACILITIES } & 8 & The canteen facilities are adequate \\
\hline & 9 & The transport facilities are adequate. \\
\hline & 10 & The safety provisions are adequate \\
\hline & 11 & Medical facilities are adequate \\
\hline \multirow[t]{2}{*}{ JOB SECURITY } & 12 & I am happy with the company's policies \\
\hline & 13 & Job security is based on performance \\
\hline
\end{tabular}




\section{ANALYSIS AND INTERPRETRATION WORK EXPERIENCE}

TABLE No.1

OPINION OF THE RESPONDENTS ABOUT THE WORK EXPERIENCE

\begin{tabular}{|l|l|c|c|c|c|c|c|}
\hline \multirow{2}{*}{\multicolumn{1}{|c|}{ Factors }} & \multicolumn{5}{|c|}{ Counts } & \multicolumn{5}{c|}{ Opinion } & \multirow{2}{*}{ Total } \\
\cline { 3 - 8 } & & SA & A & N & DA & SDA & \\
\hline \multirow{2}{*}{$\begin{array}{l}\text { Working hours } \\
\text { comfortable }\end{array}$} & No. of respondents & 49 & 0 & 1 & 0 & 0 & $\mathbf{5 0}$ \\
\cline { 2 - 8 } & Percentage & 98 & 0 & 2 & 0 & 0 & $\mathbf{1 0 0}$ \\
\hline $\begin{array}{l}\text { Excessive work } \\
\text { load }\end{array}$ & No. of respondents & 2 & 0 & 1 & 0 & 47 & $\mathbf{5 0}$ \\
\cline { 2 - 8 } & Percentage & 4 & 0 & 2 & 0 & 94 & $\mathbf{1 0 0}$ \\
\hline $\begin{array}{l}\text { Rest interval are } \\
\text { adequate }\end{array}$ & No. of respondents & 39 & 6 & 1 & 4 & 0 & $\mathbf{5 0}$ \\
\cline { 2 - 8 } & Percentage & 78 & 12 & 2 & 8 & 0 & $\mathbf{1 0 0}$ \\
\hline $\begin{array}{l}\text { Adequate } \\
\text { facilities provided } \\
\text { to attend the job }\end{array}$ & No. of respondents & 41 & 4 & 1 & 1 & 3 & $\mathbf{5 0}$ \\
\cline { 2 - 8 } $\begin{array}{l}\text { Work place free } \\
\text { from dust and } \\
\text { pollution }\end{array}$ & Percentage & 82 & 8 & 2 & 2 & 6 & $\mathbf{1 0 0}$ \\
\cline { 2 - 8 } & No. of respondents & 46 & 1 & 3 & 0 & 0 & $\mathbf{5 0}$ \\
\hline
\end{tabular}

From the above table, is clear that almost all (98 percent) of the respondents accept that the working hours are comfortable, vast majority (94 percent) of the respondents strongly disagree that their work load is excessive, while majority (78 percent) of the respondents strongly agree that the rest interval provided to the employees are adequate, followed by majority ( 82 percent) of the respondents srongly agree that adequate facilities are provided to the respondents to attend their jobs and finally vast majority ( 92 percent) of the respondents strongly agree that their work place is free from dust, pollution noise and also provided with proper ventilation and lighting facilities. It was found that almost all the respondents have registered their positive opinion about the experience they obtain in their work. Only a few respondents do not have any opinion and another few expressed that their rest interval is not adequate and inadequate facilities to attend their job.

\section{RELATIONSHIP WITH SUPERIORS}

TABLE No.2

OPINION OF THE RESPONDENTS ABOUT THE RELATIONSHIP WITH THEIR SUPERIORS

\begin{tabular}{|l|l|c|c|c|c|c|c|}
\hline \multirow{2}{*}{ Factors } & \multicolumn{1}{|c|}{ Counts } & \multicolumn{5}{|c|}{ Opinion } & \multirow{2}{*}{ Total } \\
\cline { 2 - 7 } & & SA & A & N & DA & SDA & \\
\hline $\begin{array}{l}\text { Easy to } \\
\text { approach the } \\
\text { boss }\end{array}$ & $\begin{array}{l}\text { No. of } \\
\text { respondents }\end{array}$ & 50 & 0 & 0 & 0 & 0 & $\mathbf{5 0}$ \\
\cline { 2 - 8 } & Percentage & 100 & 0 & 0 & 0 & 0 & $\mathbf{1 0 0}$ \\
\hline
\end{tabular}




\begin{tabular}{|l|l|c|c|c|c|c|c|}
\hline $\begin{array}{l}\text { Superiors } \\
\text { appreciation on } \\
\text { performance }\end{array}$ & $\begin{array}{l}\text { No. of } \\
\text { respondents }\end{array}$ & 48 & 1 & 0 & 1 & 0 & $\mathbf{5 0}$ \\
\cline { 2 - 7 } & Percentage & 96 & 2 & 0 & 2 & 0 & $\mathbf{1 0 0}$ \\
\hline $\begin{array}{l}\text { Mutual respect } \\
\text { towards opinion } \\
\text { / criticism }\end{array}$ & $\begin{array}{l}\text { No. of } \\
\text { respondents }\end{array}$ & 49 & 0 & 0 & 1 & 0 & $\mathbf{5 0}$ \\
\cline { 2 - 8 } & Percentage & 98 & 0 & 0 & 2 & 0 & $\mathbf{1 0 0}$ \\
\hline
\end{tabular}

Source: Primary Data.

The above table No. 2, shows that all (100 percent) of the respondents strongly agree that the approach towards their boss is very easy, whereas vast majority (96 percent) of the respondents strongly disagree that their superiors appreciate on their job performance and finally almost all (98 percent) of the respondents strongly agree that there exists a mutual respect among the respondents and their superiors on expressing their opinion / criticism. It is evident that vast majority of the respondents have expressed their positive opinion towards the relationship with their superiors. Only a few respondents do not have any opinion and another few expressed that their rest interval is not adequate and inadequate facilities to attend their job.

\section{RELATIONSHIP WITH COLLEAGUES}

TABLE No.3

OPINION OF THE RESPONDENTS ABOUT THE RELATIONSHIP WITH THEIR COLLEAGUES

\begin{tabular}{|l|l|c|c|c|c|c|c|}
\hline \multirow{2}{*}{ Factors } & \multicolumn{1}{|c|}{ Counts } & \multicolumn{5}{c|}{ Opinion } & \multirow{2}{*}{ Total } \\
\cline { 2 - 8 } & & SA & A & N & DA & SDA & \\
\hline $\begin{array}{l}\text { Cordial } \\
\text { working } \\
\text { environment }\end{array}$ & No. of respondents & 50 & 0 & 0 & 0 & 0 & $\mathbf{5 0}$ \\
\cline { 2 - 8 } & Percentage & 100 & 0 & 0 & 0 & 0 & $\mathbf{1 0 0}$ \\
\hline $\begin{array}{l}\text { Helpful } \\
\text { among } \\
\text { colleagues }\end{array}$ & No. of respondents & 50 & 0 & 0 & 0 & 0 & $\mathbf{5 0}$ \\
\cline { 2 - 9 } & Percentage & 100 & 0 & 0 & 0 & 0 & $\mathbf{1 0 0}$ \\
\hline
\end{tabular}

The above table No. 3 shows that all (100 percent) the respondents strongly agree that the there is a cordial working environment exists in their department and another 100 percent of the respondents have also strongly agreed that their colleagues are helpful among each other.It is clear that all (100) the respondents have strongly agree that there is a cordial working environment in their departments and colleagues are helpful among each other as well. 
MOTIVATION AND RECOGNITION

TABLE No.4

OPINION OF THE RESPONDENTS ABOUT THE MOTIVATION AND

RECOGNITION

\begin{tabular}{|l|l|c|c|c|c|c|c|}
\hline \multirow{2}{*}{ Factors } & \multicolumn{1}{|c|}{ Counts } & \multicolumn{5}{c|}{ Opinion } & \multirow{2}{*}{ Total } \\
\cline { 3 - 8 } & SA & A & N & DA & SDA & \\
\hline \multirow{2}{*}{$\begin{array}{l}\text { Job is interesting } \\
\text { and prospective }\end{array}$} & No. of respondents & 47 & 3 & 0 & 0 & 0 & $\mathbf{5 0}$ \\
\cline { 2 - 9 } & Percentage & 94 & 6 & 0 & 0 & 0 & $\mathbf{1 0 0}$ \\
\hline \multirow{2}{*}{$\begin{array}{l}\text { Satisfied about the } \\
\text { recognition }\end{array}$} & No. of respondents & 50 & 0 & 0 & 0 & 0 & $\mathbf{5 0}$ \\
\cline { 2 - 9 } & Percentage & 100 & 0 & 0 & 0 & 0 & $\mathbf{1 0 0}$ \\
\hline \multirow{2}{*}{$\begin{array}{l}\text { Proud to work in the } \\
\text { organization }\end{array}$} & No. of respondents & 39 & 7 & 4 & 0 & 0 & $\mathbf{5 0}$ \\
\cline { 2 - 9 } & Percentage & 78 & 14 & 8 & 0 & 0 & $\mathbf{1 0 0}$ \\
\hline \multirow{2}{*}{$\begin{array}{l}\text { Recognition through } \\
\text { statutory benefits }\end{array}$} & No. of respondents & 23 & 8 & 4 & 8 & 7 & $\mathbf{5 0}$ \\
\cline { 2 - 9 } & Percentage & 46 & 16 & 8 & 16 & 14 & $\mathbf{1 0 0}$ \\
\hline $\begin{array}{l}\text { Satisfied towards } \\
\text { non- statutory } \\
\text { benefits }\end{array}$ & No. of respondents & 49 & 1 & 0 & 0 & 0 & $\mathbf{5 0}$ \\
\cline { 2 - 9 } & Percentage & 98 & 2 & 0 & 0 & 0 & $\mathbf{1 0 0}$ \\
\hline
\end{tabular}

The above table No. 4 , shows that vast majority (94 percent) the respondents strongly agree that their job is interesting and prospective, while all (100 percent) of the respondents strongly agree that they are satisfied when their performance is recognized, whereas majority (78 percent) of the respondents strongly agree that they feel proud to work in this organization, nearly half (46 percent) of the respondents strongly agree, and 16 percent of the respondents agree about the recognition is through increment in their salary and another 16 percent disagree about the same. Finally, almost all (98 percent) of the respondents strongly agree that they are satisfied about the recognition through promotion. It is clear that almost all of the respondents strongly agree about the organisation's recognition which is motivating the respondents in their job.

\section{SALARY}

TABLE No.5

OPINION OF THE RESPONDENTS ABOUT THE SALARY

\begin{tabular}{|l|l|c|c|c|c|c|c|}
\hline \multirow{2}{*}{ Factors } & \multicolumn{1}{|c|}{ Counts } & \multicolumn{5}{c|}{ Opinion } & Total \\
\cline { 3 - 9 } & SA & A & N & DA & SDA & \\
\hline $\begin{array}{l}\text { Present Salary and } \\
\text { their efforts }\end{array}$ & $\begin{array}{l}\text { No. of } \\
\text { respondents }\end{array}$ & 29 & 5 & 0 & 12 & 4 & $\mathbf{5 0}$ \\
\cline { 2 - 9 } & Percentage & 58 & 10 & 0 & 24 & 8 & $\mathbf{1 0 0}$ \\
\hline
\end{tabular}




\begin{tabular}{|l|l|c|c|c|c|c|c|}
\hline $\begin{array}{l}\text { Expectation towards } \\
\text { change in pay scale }\end{array}$ & $\begin{array}{l}\text { No. of } \\
\text { respondents }\end{array}$ & 30 & 2 & 4 & 1 & 13 & $\mathbf{5 0}$ \\
\cline { 2 - 8 } & Percentage & 60 & 4 & 8 & 2 & 26 & $\mathbf{1 0 0}$ \\
\hline
\end{tabular}

Source: Primary Data.

From the above table No. 5, it is evident that most (68 percent) of the respondents strongly agree and agree that the present salary and their efforts are commensurate enough and the remaining 32 percent of the respondents disagree and strongly disagree respectively. With regards the pay scale, most (64 percent) of the respondents strongly agree that they expect changes in their present pay scale and the remaining 28 percent of the respondents do not have any expectations while 8 percent of the respondents do not have any opinion towards the expected changes in the present pay scale. It is understood that majority of the respondents are satisfied towards the present salary structures and procedures followed by the company.

\section{WELFARE FACILITIES}

TABLE No.6

OPINION OF THE RESPONDENTS ABOUT THE WORK EXPERIENCE

\begin{tabular}{|l|l|c|c|c|c|c|c|}
\hline \multirow{2}{*}{ Factors } & \multicolumn{1}{|c|}{ Counts } & \multicolumn{5}{c|}{ Opinion } & \multirow{2}{*}{ Total } \\
\cline { 3 - 8 } & SA & A & N & DA & SDA & \\
\hline $\begin{array}{l}\text { Adequate } \\
\text { Canteen } \\
\text { facilities }\end{array}$ & No. of respondents & 32 & 3 & 1 & 1 & 13 & $\mathbf{5 0}$ \\
\cline { 2 - 8 } & Percentage & 64 & 6 & 2 & 2 & 26 & $\mathbf{1 0 0}$ \\
\hline $\begin{array}{l}\text { Adequate } \\
\text { Transport } \\
\text { Facilities }\end{array}$ & No. of respondents & 47 & 1 & 1 & 1 & 0 & $\mathbf{5 0}$ \\
\cline { 2 - 8 } $\begin{array}{l}\text { Adequate } \\
\text { Safety } \\
\text { provisions }\end{array}$ & Percentage & 94 & 2 & 2 & 2 & 0 & $\mathbf{1 0 0}$ \\
\hline $\begin{array}{l}\text { Adequate } \\
\text { medical } \\
\text { facilities }\end{array}$ & Percentage & 48 & 0 & 0 & 1 & 1 & $\mathbf{5 0}$ \\
\cline { 2 - 8 } & No. of respondents & 48 & 1 & 1 & 0 & 0 & $\mathbf{5 0}$ \\
\hline
\end{tabular}

From the above table No.6, it is understood that majority (70 percent) of the respondents agree and strongly agree that there is an adequate Canteen facility and the remaining (28 percent) of the respondents disagree and strongly disagree. Vast majority (94 percent) of the respondents accept that the company provides adequate transport facility, 96 percent of the respondents strongly agree that the company provides adequate safety facilities and finally another 96 percent of the respondents strongly agree that the company provides adequate medical facilities to their employees.It is understood that majority of the respondents are satisfied about the welfare facilities like Canteen, Transport, Safety Provision and Medical facilities provided by the organisation. 
TABLE NO.7

DEPENENT VARIABLE - OVERALL OPINION ON JOB SATISFACTION

\begin{tabular}{|c|c|c|c|c|c|c|c|c|c|}
\hline \multicolumn{9}{|c|}{ Paired Samples Test } & \multirow{4}{*}{$\begin{array}{l}\text { Sig. (2- } \\
\text { tailed) }\end{array}$} \\
\hline \multirow[t]{3}{*}{ variable } & \multicolumn{5}{|c|}{ Paired Differences } & \multirow{3}{*}{$\begin{array}{c}\text { T - } \\
\text { value }\end{array}$} & \multirow{3}{*}{$\begin{array}{c}\text { Corre } \\
\text { lation } \\
\text { coeffic } \\
\text { ient }\end{array}$} & \multirow[t]{3}{*}{ P.value } & \\
\hline & \multirow[t]{2}{*}{ Mean } & \multirow[t]{2}{*}{$\begin{array}{c}\text { Std. } \\
\text { Deviation }\end{array}$} & \multirow[t]{2}{*}{$\begin{array}{l}\text { Std. } \\
\text { Error } \\
\text { Mean }\end{array}$} & \multicolumn{2}{|c|}{$\begin{array}{l}\text { 95\% Confidence } \\
\text { Interval of the } \\
\text { Difference }\end{array}$} & & & & \\
\hline & & & & Lower & Upper & & & & \\
\hline Work experience & 0.34 & 1.17 & 0.04 & 25709 & .000 & 7.88 & .276 & $0.000 * *$ & $\mathbf{S}$ \\
\hline $\begin{array}{l}\text { Relationship with } \\
\text { colleagues }\end{array}$ & 1.16 & 1.32 & 0.05 & 1.06182 & .023 & 23.74 & .084 & $0.000 * *$ & $\mathbf{S}$ \\
\hline Relationship with supervisor & 0.02 & 1.22 & 0.05 & -.07390 & .000 & 120.33 & .201 & 0.74 & $\mathrm{~s}$ \\
\hline Motivation and Recognition & 0.38 & 0.88 & 0.03 & 31261 & .000 & 11.54 & .528 & $0.000 * *$ & $\mathbf{S}$ \\
\hline Salary & 0.43 & 1.07 & 0.04 & .35628 & .000 & 10.93 & .415 & $0.000^{* *}$ & $\mathbf{S}$ \\
\hline Welfare facilities & 0.05 & 1.31 & 0.05 & -.04741 & .000 & 13.99 & .458 & 0.324 & $\mathbf{S}$ \\
\hline
\end{tabular}

** Significant at 1 per cent level. S- Significant

It has been inferred from the $\mathrm{t}$ test that the $\mathrm{p}$-value (.000) has been less than 0.01 and 0.05 the result has significance at 1 per cent level and 5 per cent level. Hence, the null hypothesis $\left(\mathrm{H}_{0}\right)$ has been rejected and the alternative hypothesis $\left(\mathrm{H}_{1}\right)$ has been accepted. From the analysis it has been concluded that there is a significant relationship between Work experience, Relationship with colleagues, Relationship with supervisor, Motivation and Recognition Salary and welfare facilities and job satisfaction.

\section{SUGGESTIONS OF THE STUDY}

- Talking and hearing throughout the day may result in deffness in future to the respondents. Management shall take this matter seriously to protect the employee's welfare and provide some-other alternative technique to overcome this current problem.

- Understand and solve their problems through proper counseling and guidance through awareness programmes.

- Active promotion and positive relation among co-workers and supervisory class is a must.

- Provide formal and informal, vertical and horizontal channels of communication is required for relaxing the respondents mentally.

- Give more importance to recreational activities by conducting outing and mind refreshing sessions, organizing workshops and discussions are essential to enable the employees enabled services to get more acquaintance relating to their job nature.

- Redressing grievances, then and there to keep the employee and their colleague's relationship intact.

- Provide relaxation techniques like yoga and meditation may be arranged by the organization. 


\section{CONCLUSION}

Science and technology are advancing day-by-day in the society. Today's society is accepting all these changes. These changes cause different problems in the society. The researcher conducted a study on job satisfaction among employees in TBF enabled service sector. In this competitive field they are facing a lot of stress and the problems faced by the employees. This study cameout with certain findings based on which the suggestions were contributed by the researcher. The researcher found that nearly half of the respondents were having problems working environment enabled in this industry. This can be avoided through counseling, recreational activities and relaxation techniques. Most of the respondents did not have any problem at all. This is a positive result obtained from the respondents. As employees services are considered as emerging field, the problems of the employees will definitely affect their profession and so conflicts in all the aspects should be eliminated.

\section{REFERENCE}

1. International Labor Organization (ILO) Report (1999), Volume 2, pp.64-68

2. M. Mallikarjun Kharge (2003), a report on status of unorganized sectors in Indian with special reference to selected industries.pp.23-26

3. Tripathi,P.C. and Kapoor N.D(2009), Personnel Management and Industrial Laws, Sultan Chand \& Sons, New Delchi, pp.125-129.

4. Dr.Deepak chawla and Dr Neena Sondhi (2011), Research Methodology. Concepts and cases”, UBS Publishers, New Delhi, pp.73-35

5. V.S.P.Rao(2010), Human Resouce Management, Excel Publications, New Delhi, pp.165169. 